\title{
PROCESS OF CREATION SOCIAL INNOVATION AS A EXAMPLE OF INNOVATION IN SERVICES ACCORDING TO THE CASE OF CULTURE AND CREATIVE INDUSTRIES INCUBATOR IN SZCZECIN
}

\section{MONIKA TOMCZYK, ${ }^{1}$ MONIKA SPYCHALSKA-WOJTKIEWICZ ${ }^{2}$}

\begin{tabular}{|c|c|}
\hline & $\begin{array}{l}\text { University of Szczecin, POLAND } \\
1 \text { e-mail: monika.tomczyk@wzieu.pl } \\
2 \text { e-mail: monika.wojtkiewicz@wzieu.pl }\end{array}$ \\
\hline $\begin{array}{l}\text { RECEIVED } \\
\text { ACCEPTED }\end{array}$ & $\begin{array}{l}1 \text { February } 2016 \\
1 \text { September } 2016\end{array}$ \\
\hline $\begin{array}{l}\text { JEL } \\
\text { CLASSIFICATION }\end{array}$ & M31, M39 M20, M29 \\
\hline KEYWORDS & social innovation, nontechnological innovation, creative industries, incubator \\
\hline ABSTRACT & $\begin{array}{l}\text { There is a growing need to reconcile the global discourse around the cultural and creative industries with } \\
\text { the needs of the local community in building both creative places and initiatives, including the creation of } \\
\text { social innovation which will contribute to make changes and building social capital which refers not only to the } \\
\text { institutions, relationships, but also to norms that shape the quality and quantity of a society's social interactions. } \\
\text { With respect to the local culture and creative industries in Szczecin, Culture Incubator was established to } \\
\text { bring together artists working in the fields of culture, arts and heritage. The activities are concentrated in } \\
\text { the Incubator of Culture to contribute to strengthening regional potential of cultural diversity and its ability to } \\
\text { implement innovative solutions and services that improve the quality build added value to the life of the local } \\
\text { communitys. }\end{array}$ \\
\hline
\end{tabular}

\section{Introduction}

The article presents a case study Culture Incubator model in the regional market - Szczecin in Poland. On the basis of this case study model of social innovation has been deployed to carry out the changes in the local culture of innovation at community level and society. In this study business model approach was presented as a way of designing innovation in services in order to strengthen local artists in getting into the creative process of emerging 
artistic community. The results show a lot of different drivers, and a combination of factors that determine success in the organization of creative culture in the regional market.

\section{Literature review}

The ambiguity of the concept of innovation provides many opportunities for its interpretation. This aspect offers the possibility of examining innovation on many levels, in a way convenient for many customers, and thus, brings the opportunity to grow economies through innovation, creative skills not only scientists, researchers, but also other members of societies in different forms not only technological developments but and social (Olejniczuk-Merta, 2013).

By analyzing models of innovation we can see that innovation is not only the result of the evolution of economic phenomena but also social processes involving people on many levels and from different backgrounds not only in economical approach. We can observe rapid development of the concept of innovation in a social context. Just as a general term innovation and also social innovation is defined broadly and in many ways.

According to the European Commission's concept of social innovation means developing new ideas, services, with the participation of public and private stakeholders, including civil society, to better solve social problems and improve social services (Figure 1). Considering the social innovation wider in general, it should be interpreted as new ideas, products, or models for actions that meet societal needs and create new social relations and cooperation between different interest groups in society (Kwaśnicki, 2013).

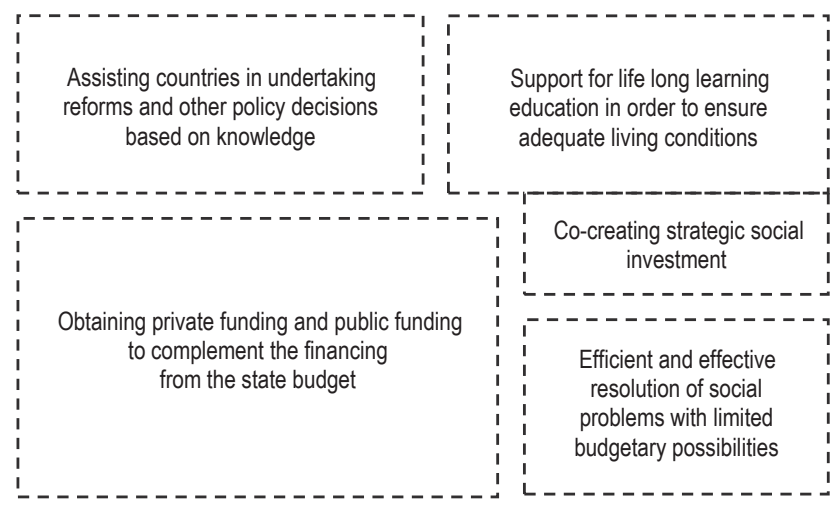

Figure 1. Social innovations possible areas of application

Source: http://ec.europa.eu/social/main.jsp?

It is noted that in order to ensure sustainable development socially, economically and environmentally new idea at social policy, health and employment policy is necessary. It is therefore necessary to develop innovative approach to education, training and skills development, supporting entrepreneurship, development of cities, regions, and many other issues. Social innovation can be a appropriate solution in this area. Social innovation will play a crucial role in addressing several key areas like supporting people in life long learning, strengthen evidence - based knowledge in policy making and also bring private and non-governmental partnerships. 
The process of creating social innovation do not particularly entrenched by numerous of methodological requirements. According to the European Commission social innovativeness measures those activities that are based on the original use of the resources shown in the diagram below (Figure 2).

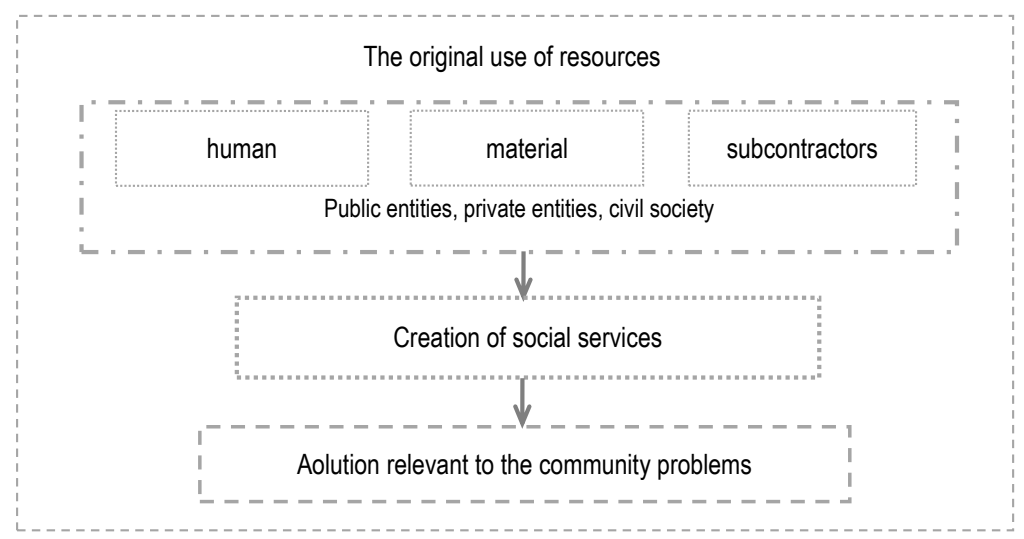

Figure 2. The process of creating social innovations

Source: own compilation based on Olejniczuk-Merta (2013), p. 21.

A characteristic feature of social innovation should be no restrictions in proposing new solutions. They should break the existing schemes, should be innovative in their approach to solving social problems. This may involve the use of both proven solutions for new social groups or activity area, as well as to develop fresh, and even experimental solutions for well-known but still important issues (Dabek, 2015). Fromyear to year can be seen more and more examples of social innovation both in the European Union, as well as in Poland.

\section{Method}

Creative industry covers actions that stem from individual creativity and talent, and which are both potential wealth and employment creation through the generation and exploitation of intellectual property rights (Podwójna ochrona dla kreatywnych, 2015). The creative sector is recognized for several years as a sector that is going to be a motor for development in Europe, being among other things, one of the largest employers in Europe.

Creativity is crucial for sector and contributes actively to the creation and development of social innovations. What's more, the creative sector includes in its scope a number of industries (advertising, film and video, architecture, music etc.) that can naturally create social innovations based on the novelty, the use of new media, art and social inclusion. Multidimensionality is needed for development of innovation, social innovation as well as in the creative industries so that they can become an instrument of multiple layers of socio-economic development. Role of interaction design and interaction designers in social innovation is very important and should covers areas of activates creating creative communities, collaborative services, collaborative consumption, sustainability ecological, social and economical, designing networks, policy and governance. Creative industries have lots of aspect which presents the figure below. 
The social aspect: creative industries are gaining more and more influence on the level of employment in the region; depending on the state of development in the country, this sector may constitute $2-8 \%$ percent of all employment

The economic aspect: trade in the creative sector is becoming increasingly important branch of world trade, global exports of visual arts in recent years has increased

Sustainable development: environment as well as cultural capital also needs to be protected; the creative sector is also in his ideas environmentally friendly

The cultural aspect: creative industries are a bridge that connects culture and economics; on the one hand are culture-factor, on the other hand they are the way by which that culture affects the economy and society

Figure 3. The dimensions of the creative industries

Source: „Analiza potrzeb i rozwoju przemysłów kreatywnych” made on behalf of the Ministry of Economy and „Newslettera przemysłów kreatywnych" formed under the Creative self-employed, Przemysły kreatywne (2015).

Social innovation through its interdisciplinary and innovative character are present in the creative sector entities not only in theory but also in practice. This connection can be observed through the application of design thinking tools in the development of social innovations. This application is a relatively natural because in order to successfully implementation of innovative solutions in the social space can not be done without empathy and a thorough understanding of the needs of society (Design Thinking, innowacje społeczne, kreatywność, 2014).

Designers have traditionally focused on enhancing the look and functionality of products. Recently, they have begun using design techniques to tackle more complex problems, such as finding ways to provide for example low-cost healthcare, environmental friendly production. Businesses were the first to embrace this design thinking approach and nonprofits organizations are beginning to adopt it too (Brown, Wyatt, 2010). Creativity plays a fundamental role in social innovation. Creative spill-over is a process by which the interactions between artists, creative professionals and industries and/or cultural organisations contribute to economic and/or social innovation in other sectors of the economy or society. The spill-over process takes place when creativity originating from culture and creative professionals and industries influences innovation in sectors where culture and creative professionals do not usually evolve. Spill-over is about processes questioning rigidity and contesting the systematic, relying on the unpredicted able or unwanted surprises born from the meeting of diverse skills and competences (European Commission DGEAC, 2010).

\section{Resulls}

Contemporary literature, especially the one from United States, is discussing issues related to innovation and the development of the company, stresses the importance of business models that determine the way in which the company/organization utilizing its resources and expertise, affects the market position and its growth. The business model can therefore be used to describe the company for which only innovative solution does not guarantee 
success, if it doesn't have a customized network of partners, distribution channels, resources, key activities, offers, customer relations, customer segments, as well as the cost structure and income.

Osterwalder and Pigneur (2010) show the business model as a conceptual tool comprising a set of elements and their relationships, and allowed to characterize the company's business logic. However, few studies have focused on implementing the business models of organizations operating in the cultural and creative industries.

There are different approaches to the concept of business models that make it difficult to clearly identify those factors that have the greatest impact on companies operating logic. In addition, the business models are an important tool to facilitate decision-making. The exact structure of the current business model and an example of the logical components of enterprises "and determine the strategic direction of the organization.. The business model is also an open system organizations, including relationships with environmental organizations, with where supply is taken then converted outputs (products, services, funds), and then forwards them to the environment. There is a certain value of all the stages of transition, from conception - The idea of meeting the needs of the environment The key to success is planning and coordinating of strategies, in line with customer expectations. As well as controlling the activities, which the company introduced to the market in order to benefit on the basis of promises and uses what he receives in return. An example of definition where the money is the main theme is the definition of Malone (2004). The definition of this author says, that the business model describes what the company does to earn money. The business model by Afuah (2004) presents its as a set of actions, which the company leads the way and deadlines for their implementation so as to ensure benefits for customers and profit for themselves. As suggested by Obłój (2002), the business model is to combine technology and business strategic concept and its practical implementation. Osterwalder and Pigneur (2010) are the most popular authors recently writing and studying business models that assume that the business model is a tool that includes a set of components and their relationships, allowing to characterize the company's business logic. According to Osterwalder and Pigneur (2010) the business model of the organization canvas must be completed. To present these key activities are the following points taken into consideration: novelty, productivity, personalization, aesthetic value and quality of design, brand, price, cost reduction, risk reduction, accessibility and usability. Information on relationships with customers may be related to customer service, personalized customer service, self-service, and contribute to the leading product/ service. The exact characteristics of the clients must also solve the problem: the mass market, niche market, multilateral segment of the market, market. The cost structure refers to the main sources of costs generated by the organization.

\section{Results supply}

"Media Dizajn" Association has used process of design thinking to create the Incubator of Culture. To achieve multi-perspective co-creative business model that suggested by Osterwalder and Pigneur was also used (2010). Culture Incubator funded by the local government Szczecin in 2011, focuses mainly on non-profit organizations working in the field of culture, arts, heritage and people working in the same area. The value proposition is to help those associated partners become self-empowerment organizations operating in the cultural and creative industries, in a period no longer than 30 months. In addition, the aim of the incubator is to support artists, becoming a reliable partner in business, science, public administration and industrial relations.

The authors considered Incubator of Culture in the ecosystem in order to create value and innovative solutions. Key partners of the incubator comes from three different fields and constitute a government - City Hall as 
a founder and the Marshal Office of the West Pomeranian; Science - University of Szczecin and the Academy of Arts; business environment institutions Technopark Pomerania.

Activities of Culture Incubator are based as an experiment model to follow not existed before. Culture Incubator clients are organizations, informal groups and individuals that are new on market or those that have low competence management and require the support of the incubator. Cultural Incubator has three segments of creative workers: associations and foundations, informal group, individual artists.

All organizations, informal groups and individuals associated in the incubator have their seat and the possibility to use paid premises - key resources (offices, open space, rooms, cinema, guest rooms), technical equipment, and services for sharing data and knowledge. It is also possible to have in incubator only postal address (virtual office) for correspondence instead of having a seat.

Culture Incubator Key actions include education process, sharing knowledge and experience through participation in free workshops, seminars and consultations. This education in the field of accounting, finance, marketing, copyrights, applying for external funding, including grants and participation in projects. The aim of the creative workforce education is to prepare them in the incubation period for the management of autonomous nonprofit organizations. Currently, new sessions are away, "let's go together" - multi-day trips for representatives of the creative class. In addition to the whole key activities of the Incubator of Culture, numerous relationships with customers, which are held every year are modified. The purpose of customer relationships is to strengthen cooperation between related organizations and continue it in the long run. The result is to establish long-term partnerships and build mutual trust based on a social contract. Accordingly, Culture Incubator includes various channels (newsletter, website and social media) to present the best practices in the field of cultural and creative industries and cross-border industrial cooperation. In 2014 the main subject is focused on cultural animation. The intention was to find a cultural animation leader - a person who - with his knowledge and social competence is able to achieve long-term cooperation based on partnership relations and the environment. Culture Incubator cost structure is divided into two parts. The first part refers to the cost of maintaining the infrastructure: electricity, heating, rent and other media, which accounts for about $80 \%$ of all costs. The second part covers the costs of management and services, which is $20 \%$ of the total cost of the incubator. All costs are covered by revenue. Revenues came from the City of Szczecin Culture Incubator is a project of outsourcing public services conducted by the Media Dizajn Association. The idea of - this project is to revitalize Villa - based infrastructure in the city center, which should offer services in the cultural sector. As one of latest initiative of Incubator of Culture was project Recreation - Professional Social Manager. Intensive work, planning and acquiring leadership skills, and non - formal education. Recreation team creates a group of animators from the Szczecin Metropolitan Area and designated in the recruitment process. 21 leaders designed together 7 micro project that came directly from end users - citizens of city needs. Some ideas are still in operation even if the projects ends.

\section{Conclusions}

During the study we found that business model as a tool for containing conceptual elements and their relationships allowed the identification of non-profit organizations operating in the business logic in the cultural sector. These results extend those Osterwalder and Pigneur confirming that the logic of the local cultural industry structure, under which the organization makes a profit, and provides added value from the use of the environment, while meeting clients, determines the success of not - profit organizations in the cultural sector. In addition, we have 
created an interdisciplinary team to meet the needs of potential customers within limited competition guidelines contained in an open discussion.. In connection with this study indicate that the process of design thinking can be extended to the business model to fully identify needs and create social innovations for the cultural and creative industries in the community. Results of our study provide evidence that Culture Incubator creates conditions for local artists to get creative process emerging artistic.

\section{References}

Afuah, A. (2004). Business models. A strategic management approach. New York: McGraw-Hill Irwin.

Brown, T. \& Wyatt, J. (2010). Design Thinking for Social Innovation. Available at: http://www.ssireview.org/articles/entry/design thinking_for_social_innovation (December 2015).

Kwaśnicki, W. (2013). Innowacje społeczne - dobry sposób na rozwiązanie problemów społecznych? Available at: http://www.pi.gov.pl/ PARP/chapter_86197.asp?soid=B06A8565AA4D4C348A780C309987EC0C (December 2015).

Malone, T.W., Weill, P., Lai, R.K., et al. (2006). Do Some Business Models Perform Better than Others?, MIT, Working Paper 4615-06.

Obłój, K. (2002). Tworzywo skutecznych strategii. Warszawa: PWE.

Olejniczuk-Merta, A. (2013). Innowacje społeczne. Konsumpcja i Rozwój, 1.

Osterwalder, A. \& Pigneur, Y. (2010). Business Model Generation. New York: Willey.

Podwójna ochrona dla kreatywnych (2015). Available at: http://www.gazetaprawna.pl/podwojna_ochrona (December 2015).

Przemysły kreatywne (2015). Available at: http://www.kreatywna.lodz.pl/page/13,przemysly-kreatywne.html.

Social innovation (2013). Available at: http://ec.europa.eu/social/main.jsp?catld=1022 (December 2015).

The Theoretical, Empirical and Policy Foundations for Social Innovation in Europe (2015). Available at: http://siresearch.eu/socialinnovation/project/tepsie (December 2015).

Cite this article aS:" Tomczyk, M., Wojtkiewicz, M. (2016). Process of creation social innovation as a example of innovation in services according to the case of Culture and Creative Industries Incubator in Szczecin. European Journal of Service Management, 20 (4), 67-73. DOI: 10.18276/ejsm.2016.20-08. 
